\title{
Apple Tree Performance with Mechanical Hedging or Root Pruning in Intensive Orchards
}

\author{
David C. Ferree and W. Timothy Rhodus \\ Department of Horticulture, Ohio Agricultural Research and Development Center, The Ohio State \\ University, Wooster, OH 44691
}

Additional index words. central leader, Malus domestica, tree density, trellis

\begin{abstract}
Annual mechanical hedging in August or root pruning at bloom was used to control the growth of four apple (Malus domestica Borkh.) cultivars in two orchard systems planted at half the recommended in-row spacing. Trunk cross-sectional area (TCA) per hectare on the trellis system was $30 \%$ higher, a result that correlated $(r=0.80)$ to a $40 \%$ higher cumulative yield per hectare over 10 years compared to the central leader system. Over 10 years, the cumulative yield and TCA per hectare of 'Smoothee Golden Delicious', 'Empire', and 'Redchief Delicious' were higher in the trellis than the central leader system, while these characteristics of 'Lawspur Rome Beauty' were not influenced by orchard system. 'Lawspur' had the highest TCA per hectare, cumulative yield per hectare, and greatest tendency toward biennial bearing of the four cultivars. Root pruning reduced all tree-size measurements, while hedging did not influence tree height or average shoot length. Yield and yield per TCA were reduced by hedging and root pruning, with the greatest reduction in yield caused by root pruning. Hedging increased cumulative yield per hectare with root-pruned trees intermediate between hedged standard-spaced trees. Trellis trees had a higher density of spurs and shoots and a higher leaf area index than trees on the central leader system. An evaluation of the treatment combinations using net present value analysis indicated that none of the treatments was a profitable investment. Of the top twelve treatments, as evaluated for 10 years, nine were the central leader and three the trellis system, with none of the trellis and only four of the central leader treatments being hedged or root-pruned. Results of this study indicate that orchard intensification is accomplished best by choosing appropriate planting distances and not by attempting to control growth mechanically on trees planted too close for optimum performance.
\end{abstract}

The need to improve apple orchard productivity and profitability has resulted in the use of new orchard management systems (Jackson and Palmer, 1989). The most proven method of increasing orchard efficiency is to intensify planting in these systems using a precocious, size-controlling rootstock combined with an appropriate management system (Barritt, 1989; Ferree et al., 1989b; Robinson et al., 1991). Unfortunately, many of the most precocious and efficient dwarfing rootstocks are susceptible to fireblight and significant losses can occur (Ferree et al., 1983). Generally it is uneconomical to plant trees on more vigorous rootstocks at very close spacings without some additional means to control size due to increased pruning costs and the tendency of the trees to produce excessive vegetative growth at the expense of fruiting.

Mechanically hedging dormant trees, or during the summer, has been tried with only limited success (Ferree, 1976, 1979). Root pruning is another mechanical means of controlling tree size. Root pruning reduces growth, pruning time, preharvest drop, and fruit size while increasing fruit firmness and soluble solids concentration and improving fruit color (Ferree, 1992; Schupp and Ferree, 1987, 1988; Schumacher, 1975). Most of these studies on root pruning have been conducted on mature trees, but this technique has not been compared directly to other orchard systems or techniques designed to improve orchard efficiency.

The present study was established to determine if mechanical summer hedging or root pruning could contain the growth of trees planted at double their recommended density in two orchard systems. In addition, the influence of the systems and treatments

Received for publication 23 Sept. 1992. Accepted for publication 14 Feb. 1993. Salaries and research support provided by state and federal funds appropriated to the Ohio Agricultural Research and Development Center, The Ohio State University. Journal article no. 264-92. The cost of publishing this paper was defrayed in part by the payment of page charges. Under postal regulations, this paper therefore must be hereby marked advertisement solely to indicate this fact. on orchard efficiency, canopy composition, and economic performance were evaluated.

\section{Materials and Methods}

In 1981, 'Smoothee Golden Delicious', 'Lawspur Rome Beauty', 'Redchief Delicious', and 'Empire' were established in a four-wire trellis hedgerow on M.9 rootstock or a free-standing central leader on M.7 rootstock. A three-tree plot of each combination was established in a series of three plots per row at the recommended spacing for that cultivar and rootstock ('Smoothee' and 'Empire'-M.7, 4.5×6m; M.9, 2.5×3.5m; 'Redchief and 'Lawspur'M.7, $3.5 \times 5 \mathrm{~m}$, M.9, $2 \times 3.5 \mathrm{~m}$ ) and two plots were established in each row at half the recommended in-row spacing, with all rows running north to south. Trees in the plots at half spacing were either root-pruned or mechanically hedged. We recognized that the effects of spacing and either hedging or root pruning are confounded in this study; thus, even though the treatments are referred to as either hedged or root-pruned, the effects could be due, partly or totally, to the closer spacing. Root pruning on two sides of the trees $50 \mathrm{~cm}$ from the trunk and $35 \mathrm{~cm}$ deep was begun in 1983 and repeated annually at bloom with a tractor-drawn subsoiler (Geisler and Ferree, 1984) cutting at the same location each year. Trees were hedged annually in early August on two sides with a two-bladed sickle-bar mower set at a $75^{\circ}$ angle. The mower was positioned to remove $15 \mathrm{~cm}$ of growth from the east and west sides of the canopy until the trees filled their allotted space and then they were cut at the same location each year. The treatments were arranged in a split-plot design of four replications, with training system as the whole plot, cultivar as the split plot and spacing-pruning as the split-split plot.

Tree height, spread, and trunk circumference were recorded annually. The yield from each tree was graded annually with a weight-sizer (FMC, San Jose, Calif.), set independently for each cultivar to divide the fruit into the following size classes, with the 
number of fruit in each size counted: Size $1=80 \mathrm{~mm}$ and larger $(80$ to 88 ); Size $2=79$ to $72 \mathrm{~mm}$ (100 to 113 ); Size $3=71$ to $57 \mathrm{~mm}$ (125 to 138); Size $4=56 \mathrm{~mm}$ and smaller. The fruit were graded according to commercial standards and culled fruit were removed and counted. Mean biennality was calculated on each pair of years using the index of Hoblyn et al. (1936) and combined into an overall mean biennality index for the 8 years with yield. The intensity of the biennial pattern increases as the index value approaches 1 .

In August 1989, detailed measurement of the canopies of six replicate trees of each combination were made with tree spread in both directions and tree height divided into thirds to create 27 sections. In the nine canopy volume sections formed by the east, central, and west transect centered on the tree, the following were counted: number of spurs, shoots, spur leaves, shoot leaves, and fruit. Because of the time involved, canopy measurements were made on 'Lawspur (Class 4), a terminal-bearing cultivar; 'Redchief (Class 1), a spur-habit cultivar; and 'Smoothee' (Class 3), which has a growth habit between that of the others, according to the classification of Lespinasse (1980). As leaves were counted, every 20th was removed and leaf area was measured (model 3000; LICOR, Lincoln, Neb.).

Light transmission in the canopy was measured with a radiometer (model LI-185B, LI-COR) with a 1-m quantum line sensor (model 1915B; LI-COR) under sunny, cloud-free, and completely overcast conditions in August 1989. The sensor was placed on the west side of the canopy $15 \mathrm{~cm}$ from and centered on the trunk $1 \mathrm{~m}$ high. Readings were taken between 12:30 and 2:00 PM, close to solar zenith, first with the sensor pointed skyward and then with the sensor pointed toward the soil.
Net present value analysis (NPV) was performed using estimated per hectare revenues and expenses for 10 years for each of the 24 treatment $\times$ cultivar combinations. A base production budget for growing apples in Ohio was established from coefficients published by the Ohio Cooperative Extension Service (1991). This included all expense items common to each treatment, such as cost per unit for planting, harvesting, chemical treatments, fertilizer applications, labor requirements, management charges, land, machinery, and overhead. Incremental cost differences associated with each treatment, in terms of materials, equipment, and labor expenses, were added to the base budget. A common selling price of $\$ 0.36 / \mathrm{kg}$ was used for each of the four cultivars and represented the average wholesale price for apples sold in Ohio between 1982 and 1990 .

\section{Results and Discussion}

Trees on M.9 rootstocks in the trellis system were smaller than trees on M.7 rootstocks in the central leader system in all the characteristics measured (Table 1). Cumulative yield per tree followed tree size; however, efficiency, as measured by yield per trunk area, was higher in the trellis trees. Trunk cross-sectional area (TCA) per hectare of the trellis system was $30 \%$ higher, a result that corresponded to a $40 \%$ higher cumulative yield per hectare compared to the central leader system of the larger trees $(r$ $=0.80)$. Robinson and Lakso (1991) also reported a high correlation between cumulative yield and TCA per hectare in a lo-year apple system trial.

The spur-habit 'Redchief trees were the smallest and had the lowest yield per tree of the four cultivars (Table 1). 'Lawspur' had

Table 1. Influence of mechanical root pruning or summer hedging of four apple cultivars in two orchard systems on growth, tree size, and cumulative yield over 10 years. $^{\mathrm{Z}}$

\begin{tabular}{|c|c|c|c|c|c|c|c|c|c|c|c|}
\hline \multirow[b]{3}{*}{ Variable } & \multicolumn{4}{|c|}{ Tree size } & \multirow{2}{*}{\multicolumn{2}{|c|}{$\begin{array}{l}\text { Shoot } \\
\text { length } \\
(\mathrm{cm})\end{array}$}} & \multirow{3}{*}{$\begin{array}{c}\text { TCA } \\
\text { ha } \\
\left(\mathrm{m}^{2}\right)\end{array}$} & \multirow{2}{*}{\multicolumn{3}{|c|}{$\frac{\text { Cumulative yield }}{\mathrm{kg} / \mathrm{cm}^{2}}$}} & \multirow{3}{*}{$\begin{array}{c}\text { Mean } \\
\mathrm{BI}^{\mathrm{x}}\end{array}$} \\
\hline & \multirow{2}{*}{$\begin{array}{l}\mathrm{Ht} \\
(\mathrm{m})\end{array}$} & \multirow{2}{*}{$\begin{array}{l}\text { Spread } \\
(\mathrm{m})\end{array}$} & \multirow{2}{*}{$\begin{array}{l}\text { Vol } \\
\left(\mathrm{m}^{3}\right)\end{array}$} & \multirow{2}{*}{$\begin{array}{l}\mathrm{TCA}^{\mathrm{y}} \\
\left(\mathrm{cm}^{2}\right)\end{array}$} & & & & & & & \\
\hline & & & & & 89 & 90 & & $\mathrm{~kg} /$ tree & TCA & $\mathrm{t} \cdot \mathrm{ha} \mathrm{a}^{-1}$ & \\
\hline \multicolumn{12}{|l|}{$\overline{\text { System }}$} \\
\hline Trellis & $2.8 \mathrm{~b}$ & $1.5 \mathrm{~b}$ & $8.2 \mathrm{~b}$ & $40.7 \mathrm{~b}$ & $20.5 \mathrm{~b}$ & $27.0 \mathrm{a}$ & $8.4 \mathrm{a}$ & $132.9 \mathrm{~b}$ & $3.2 \mathrm{a}$ & $252.0 \mathrm{a}$ & $0.47 \mathrm{a}$ \\
\hline Central leader & $3.2 \mathrm{a}$ & $2.7 \mathrm{a}$ & $9.9 \mathrm{a}$ & $69.6 \mathrm{a}$ & $23.7 \mathrm{a}$ & $29.7 \mathrm{a}$ & $5.8 \mathrm{~b}$ & $202.8 \mathrm{a}$ & $2.6 \mathrm{~b}$ & $149.1 \mathrm{~b}$ & $0.45 \mathrm{a}$ \\
\hline \multicolumn{12}{|l|}{ Cultivar } \\
\hline Smoothee & $3.2 \mathrm{a}$ & $2.3 \mathrm{a}$ & $10.7 \mathrm{a}$ & $64.1 \mathrm{a}$ & $19.4 \mathrm{~b}$ & $25.5 \mathrm{~b}$ & $6.8 \mathrm{~b}$ & $177.5 \mathrm{a}$ & $2.8 \mathrm{a}$ & $176.1 \mathrm{bc}$ & $0.43 b c$ \\
\hline Lawspur & $2.9 \mathrm{ab}$ & $2.1 \mathrm{a}$ & $8.6 \mathrm{~b}$ & $58.8 \mathrm{a}$ & $19.9 \mathrm{~b}$ & $27.1 \mathrm{~b}$ & $8.5 \mathrm{a}$ & $194.0 \mathrm{a}$ & $3.1 \mathrm{a}$ & $256.4 \mathrm{a}$ & $0.57 \mathrm{a}$ \\
\hline Empire & $3.0 \mathrm{ab}$ & $2.3 \mathrm{a}$ & $11.0 \mathrm{a}$ & $59.7 \mathrm{a}$ & $26.1 \mathrm{a}$ & $30.7 \mathrm{a}$ & $7.0 \mathrm{~b}$ & $180.3 \mathrm{a}$ & $2.7 \mathrm{a}$ & $204.1 \mathrm{~b}$ & $0.39 \mathrm{c}$ \\
\hline Redchief & $2.8 \mathrm{~b}$ & $1.8 \mathrm{~b}$ & $6.0 \mathrm{c}$ & $37.6 \mathrm{~b}$ & $23.9 \mathrm{a}$ & $30.0 \mathrm{a}$ & $6.3 \mathrm{~b}$ & $117.2 \mathrm{~b}$ & $2.8 \mathrm{a}$ & $162.7 \mathrm{c}$ & $0.46 \mathrm{~b}$ \\
\hline \multicolumn{12}{|l|}{ Treatment } \\
\hline Standard & $3.1 \mathrm{a}$ & $2.4 \mathrm{a}$ & $14.1 \mathrm{a}$ & $68.7 \mathrm{a}$ & $24.9 \mathrm{a}$ & 29.8 a & $5.6 \mathrm{c}$ & $225.5 \mathrm{a}$ & $3.4 \mathrm{a}$ & $184.1 \mathrm{~b}$ & $0.47 \mathrm{a}$ \\
\hline Hedged & $3.1 \mathrm{a}$ & $1.7 \mathrm{c}$ & $6.9 c$ & $51.7 \mathrm{~b}$ & $22.8 \mathrm{a}$ & $29.8 \mathrm{a}$ & $8.6 \mathrm{a}$ & $145.1 \mathrm{~b}$ & $2.5 \mathrm{~b}$ & $219.3 \mathrm{a}$ & $0.45 \mathrm{a}$ \\
\hline Root pruned & $2.7 \mathrm{~b}$ & $2.1 \mathrm{~b}$ & $7.1 \mathrm{~b}$ & $45.0 \mathrm{c}$ & $18.6 \mathrm{~b}$ & $25.5 \mathrm{~b}$ & $7.0 \mathrm{~b}$ & $134.2 \mathrm{c}$ & $2.7 \mathrm{~b}$ & $196.6 \mathrm{ab}$ & $0.46 \mathrm{a}$ \\
\hline \multicolumn{12}{|l|}{ F significance } \\
\hline System (S) & $* *$ & $* *$ & $* *$ & $* *$ & $* *$ & $* *$ & $* *$ & $* *$ & $* *$ & $* *$ & NS \\
\hline Cultivar (C) & $* *$ & $* *$ & $* *$ & $* *$ & $* *$ & $* *$ & $* *$ & $*$ & NS & $* *$ & $* *$ \\
\hline $\mathrm{S} \times \mathrm{C}$ & $* *$ & $* *$ & $* *$ & $* *$ & NS & $*$ & $* *$ & NS & NS & $* *$ & $*$ \\
\hline Treatment (T) & $* *$ & $* *$ & $* *$ & $* *$ & $* *$ & $* *$ & $* *$ & $* *$ & $* *$ & $*$ & NS \\
\hline $\mathrm{T} \times \mathrm{C}$ & $*$ & $*$ & $* *$ & $*$ & NS & NS & NS & NS & NS & NS & NS \\
\hline $\mathrm{T} \times \mathrm{S}$ & NS & $* *$ & $* *$ & NS & $* *$ & NS & NS & NS & NS & NS & NS \\
\hline $\mathrm{T} \times \mathrm{C} \times \mathrm{S}$ & NS & NS & NS & NS & NS & NS & NS & NS & NS & NS & NS \\
\hline
\end{tabular}

${ }^{\mathrm{z}}$ Mean separation within main effect column by Duncan's multiple range test, $P \leq 0.05$. Data are means of the following number of observations: systems, 48; cultivar, 24; treatment, 32 .

YTCA $=$ trunk cross-sectional area.

${ }^{\mathrm{x}} \mathrm{BI}=$ biennality index.

${ }_{\text {Ns, }, * * *}$ Nonsignificant or significant at $P \leq 0.05$ or 0.01 , respectively. 
the highest TCA per hectare, cumulative yield per hectare, and greatest tendency toward biennial bearing. 'Smoothee' trees in the central leader system were less efficient than those in the trellis system, while the other cultivars did not differ in efficiency between systems (Fig. 1a). Over 10 years, the cumulative yield per hectare (Fig. 1b) and TCA per hectare (Fig. 1c) of 'Smoothee', 'Empire', and 'Redchief were higher in the trellis system than those in the central leader system. However, cumulative yield per hectare (Fig. 1b) and TCA per hectare (Fig. 1c) of 'Lawspur' were not influenced by orchard system. Robinson et al. (1991) found that cumulative yield and yield efficiency of 'Redchief' and 'Empire' differed in their long-term response to several management systems. Orchard system had no influence on tendency toward biennial bearing with 'Smoothee' or 'Lawspur'. However, the trellis reduced the biennial tendency of 'Empire' and the central leader had the same effect on 'Redchief (Fig. 1d).

Root pruning reduced all characteristics measured, while hedging had no influence on tree height or average shoot length (Table 1). However, hedging reduced spread and tree volume more than root pruning. Thus, hedging and root pruning can be used annually to contain apple trees planted closer than desirable. The $34 \%$ reduction in TCA is similar to the reduction caused by root pruning in other studies on young (Schupp and Ferree, 1987) and mature trees (Schupp and Ferree, 1988). Hedging and root pruning trees planted at half the in-row space caused a significant increase in TCA per hectare compared to the standard-spaced trees, with the greatest increase in TCA per hectare due to hedging. Yield per tree and efficiency (yield per TCA) were reduced by hedging and root pruning, with the greatest reduction in yield caused by the latter.
Hedging increased cumulative yield per hectare, with root-pruned trees being intermediate between hedged and standard-spaced trees. The interaction between cultivar and treatment was due to root pruning, which reduced growth in 'Lawspur' and 'Empire' slightly more than in 'Smoothee' and 'Redchief'.

Yield per tree was higher in 1988 and 1990 than in 1989 (Table 2). In each year, the central leader trees had a higher percentage of fruit $>80 \mathrm{~mm}$ in diameter and a lower percentage of fruit 72 to 57 $\mathrm{mm}$ in diameter, except in 1988, when percentages were similar to those of trees in the trellis system. Robinson et al. (199 1) reported that 'Empire' fruit were larger on the M.7 central leader trees than on the slender spindle or Y-trellis/M.26, while 'Redchief fruit were larger on trees in the Y-trellis than in the other systems. 'Empire' consistently had a low and 'Lawspur' a high percentage of fruit $>80 \mathrm{~mm}$ in diameter, while the other cultivars varied with year. The effects of treatment on fruit size distribution were inconsistent; but, in the light crop year of 1989, hedging and root pruning reduced the percentage of fruit $>80 \mathrm{~mm}$ in diameter, with root pruning causing the greatest reduction. The significant interaction of fruit $>80 \mathrm{~mm}$ in diameter in 1989 between cultivar and treatment resulted from root pruning, which caused $15 \%$ fewer fruit in this size class than hedging, while the differences between these treatments were small for the other cultivars. The interaction of fruit 79 to $73 \mathrm{~mm}$ in diameter resulted from root pruning, causing an increase in this size class with 'Smoothee' and 'Lawspur' and a slight reduction or no effect with 'Empire' and 'Redchief. In previous studies with 'Melrose' (Schupp and Ferree, 1987; Schupp and Ferree, 1988), 'Jonathan' (Ferree, 1992), and 'Golden Delicious' (Schupp et al., 1992), fruit size has been reduced consis-
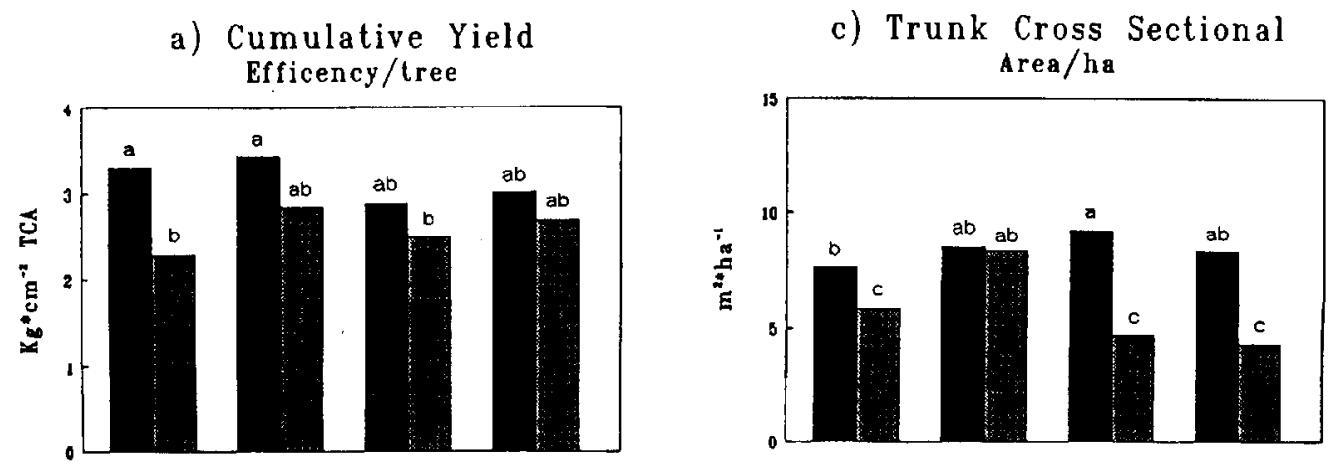

\section{b) Cumulative Yield/hectare}

d) Biennialty Index
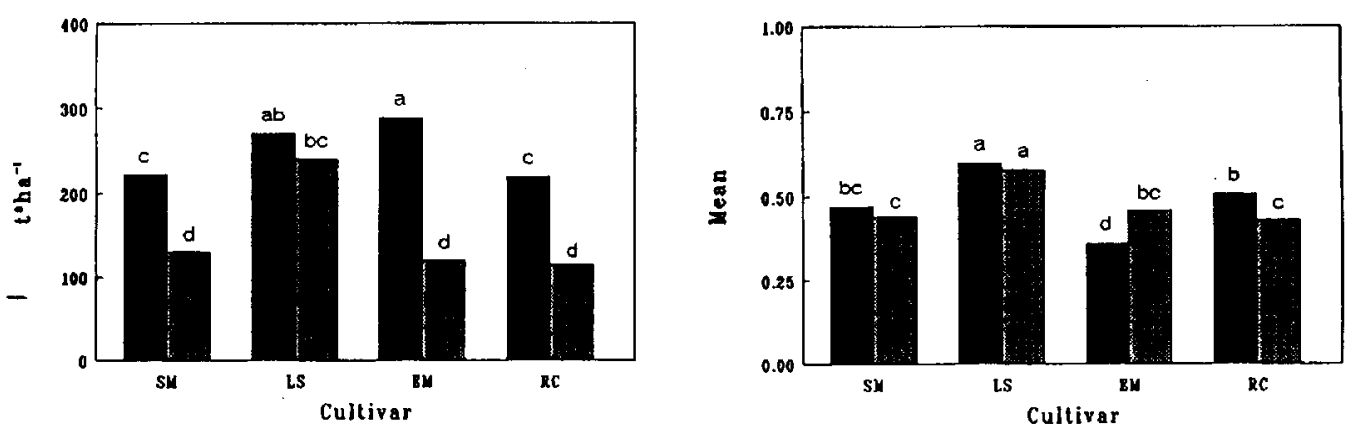

Fig. 1. Influence of trellis (left bars) and central leader (right bars) orchard management systems on (a) the cumulative yield efficiency per tree, (b) cumulative yield per hectare, (c) trunk cross-sectional area per hectare, and (d) biennality index of 'Smoothee Golden Delicious' (SM), 'Lawspur Rome Beauty' (LS), 'Empire' (EM), and 'Redchief Delicious' (RC). Data are means of 12 observations. 
Table 2. Influence of mechanical root pruning and summer hedging on fruit size distribution (diameter) of four cultivars in two orchard management systems.

\begin{tabular}{|c|c|c|c|c|c|c|c|c|c|c|c|c|c|c|c|}
\hline \multirow[b]{3}{*}{ Variable } & \multicolumn{5}{|c|}{1988} & \multicolumn{5}{|c|}{1989} & \multicolumn{5}{|c|}{1990} \\
\hline & \multicolumn{4}{|c|}{ Size distribution (mm) } & \multirow{2}{*}{$\begin{array}{c}\text { Yield } / \\
\text { tree }(\mathrm{kg})\end{array}$} & \multicolumn{4}{|c|}{ Size distribution (mm) } & \multirow{2}{*}{$\begin{array}{c}\text { Yield/ } \\
\text { tree }(\mathbf{k g})\end{array}$} & \multicolumn{4}{|c|}{ Size distribution (mm) } & \multirow{2}{*}{$\begin{array}{c}\text { Yield/ } \\
\text { tree }(\mathrm{kg})\end{array}$} \\
\hline & $>80$ & $79-73$ & $72-57$ & $\overline{\text { culls }}$ & & $>80$ & $79-73$ & $72-57$ & culls & & $>80$ & $79-73$ & $72-57$ & $\overline{\text { culls }}$ & \\
\hline \multicolumn{16}{|c|}{ Percent } \\
\hline \multicolumn{16}{|l|}{ System } \\
\hline Trellis & $19 b^{2}$ & $26 \mathrm{a}$ & $42 \mathrm{a}$ & $10 \mathrm{a}$ & $29.1 \mathrm{~b}$ & $17 \mathrm{~b}$ & $26 \mathrm{~b}$ & $37 a$ & $20 \mathrm{a}$ & $18.9 \mathrm{~b}$ & $10 \mathrm{~b}$ & $22 \mathrm{~b}$ & $45 \mathrm{a}$ & $14 \mathrm{a}$ & $24.1 \mathrm{~b}$ \\
\hline Central leader & $27 \mathrm{a}$ & $28 \mathrm{a}$ & $35 \mathrm{a}$ & $8 a$ & $50.7 \mathrm{a}$ & $21 \mathrm{a}$ & $32 \mathrm{a}$ & $33 \mathrm{~b}$ & $13 b$ & $37.0 \mathrm{a}$ & $12 \mathrm{a}$ & $36 a$ & $39 \mathrm{~b}$ & $12 \mathrm{a}$ & $46.9 \mathrm{a}$ \\
\hline \multicolumn{16}{|l|}{ Cultivar } \\
\hline Smoothee & $17 \mathrm{bc}$ & $35 \mathrm{a}$ & $42 \mathrm{~b}$ & $3 c$ & $38.4 \mathrm{~b}$ & $26 \mathrm{~b}$ & $40 \mathrm{a}$ & $16 \mathrm{c}$ & $19 \mathrm{~b}$ & $29.0 \mathrm{~b}$ & $7 \mathrm{~b}$ & $20 \mathrm{c}$ & 59 a & $12 \mathrm{~b}$ & $41.5 \mathrm{a}$ \\
\hline Lawspur & $24 \mathrm{~b}$ & $29 a$ & $32 \mathrm{bc}$ & $14 a$ & $58.1 \mathrm{a}$ & $43 \mathrm{a}$ & $38 \mathrm{a}$ & $14 \mathrm{c}$ & $5 \mathrm{c}$ & $26.1 \mathrm{bc}$ & $28 \mathrm{a}$ & $32 b$ & $33 \mathrm{~b}$ & $7 \mathrm{c}$ & $44.8 \mathrm{a}$ \\
\hline Empire & $7 \mathrm{c}$ & $29 a$ & $57 \mathrm{a}$ & $8 \mathrm{~b}$ & $36.2 \mathrm{~b}$ & $2 c$ & $31 \mathrm{~b}$ & $50 \mathrm{~b}$ & $17 \mathrm{~b}$ & $39.5 \mathrm{a}$ & $5 \mathrm{~b}$ & $41 \mathrm{a}$ & $34 \mathrm{~b}$ & $20 \mathrm{a}$ & $28.8 \mathrm{~b}$ \\
\hline Redchief & $46 a$ & $16 \mathrm{~h}$ & $25 \mathrm{c}$ & $13 \mathrm{ah}$ & $27.0 \mathrm{~b}$ & $5 \mathrm{c}$ & $8 \mathrm{c}$ & $61 \mathrm{a}$ & $26 a$ & $17.3 \mathrm{c}$ & $4 \mathrm{~b}$ & $43 \mathrm{a}$ & $40 \mathrm{~b}$ & $12 \mathrm{~b}$ & $26.8 \mathrm{~b}$ \\
\hline \multicolumn{16}{|l|}{ Treatment } \\
\hline Standard & $28 \mathrm{a}$ & $29 a$ & $32 \mathrm{~b}$ & $10.2 \mathrm{a}$ & $57.6 \mathrm{a}$ & $25 \mathrm{a}$ & $28 a$ & $33 \mathrm{~b}$ & $14 \mathrm{a}$ & $39.6 \mathrm{a}$ & $11 \mathrm{a}$ & $37 \mathrm{a}$ & $40 \mathrm{a}$ & $12 \mathrm{~b}$ & $50.9 \mathrm{a}$ \\
\hline Hedged & $19 \mathrm{~b}$ & $26 a$ & $44 \mathrm{a}$ & $10.5 \mathrm{a}$ & $34.1 \mathrm{~b}$ & $19 \mathrm{~b}$ & $30 \mathrm{a}$ & $34 \mathrm{~b}$ & $17 \mathrm{a}$ & $21.7 \mathrm{~b}$ & $12 \mathrm{a}$ & $35 \mathrm{a}$ & $41 \mathrm{a}$ & $12 \mathrm{~b}$ & $29.7 \mathrm{~b}$ \\
\hline Root pruned & $23 a b$ & $28 \mathrm{a}$ & $39 \mathrm{a}$ & $7.3 \mathrm{a}$ & $28.1 \mathrm{~b}$ & $13 \mathrm{c}$ & $29 a$ & $39 a$ & $18 \mathrm{a}$ & $22.5 b$ & $10 \mathrm{a}$ & $30 \mathrm{~b}$ & $44 a$ & $15 \mathrm{a}$ & $26.1 \mathrm{~b}$ \\
\hline \multicolumn{16}{|l|}{ F Significance } \\
\hline Cultivar (C) & $* *$ & $* *$ & $* *$ & $*$ & $* *$ & $* *$ & $* *$ & $* *$ & $* *$ & $* *$ & $* *$ & $* *$ & $* *$ & $*$ & $* *$ \\
\hline System (S) & $*$ & NS & NS & NS & $*$ & $* *$ & $* *$ & $*$ & $* *$ & $* *$ & $* *$ & $* *$ & $* *$ & NS & $* *$ \\
\hline $\mathrm{S} \times \mathrm{C}$ & NS & NS & NS & NS & NS & $*$ & $* *$ & $* *$ & $* *$ & NS & NS & $* *$ & NS & NS & ** \\
\hline Treatment $(\mathrm{T})$ & $*$ & NS & $* *$ & NS & $* *$ & $* *$ & NS & $*$ & $* *$ & $* *$ & NS & $* *$ & NS & $*$ & ** \\
\hline $\mathbf{S} \times \mathbf{T}$ & NS & NS & NS & NS & NS & $*$ & NS & NS & $* *$ & NS & NS & NS & NS & NS & NS \\
\hline $\mathrm{C} \times \mathrm{T}$ & NS & $* *$ & NS & NS & NS & $* *$ & $* *$ & NS & $* *$ & NS & NS & NS & NS & NS & $* *$ \\
\hline $\mathrm{S} \times \mathrm{C} \times \mathrm{T}$ & NS & NS & NS & NS & NS & $* *$ & NS & NS & NS & NS & * & NS & NS & NS & NS \\
\hline
\end{tabular}

${ }^{2}$ Mean separation with main effect column by Duncan' multiple range test, $P \leq 0.05$. Data are means of the following number of observations: system, 48; cultivar, 24; treatment, 32 .

Ns,***** Nonsignificant or significant at $P \leq 0.05$ or 0.01 , respectively.

tently by root pruning. However, fruit size of 'McIntosh' (Elfving et al., 1991; Scibsz, 1990) was not influenced. Thus, it seems that the effect of root pruning on fruit size may vary with cultivar, and the effects in this study were not as consistent across years as in previous long-term studies.

Training the trellis as a palmette along the wire support increased the density of spurs and shoots. This increase also was reflected in a higher leaf area index (LAI) and leaf area of spur and shoot leaves (Table 3). The tendency for canopy density to increase through training to various trellis forms has been reported previously (Ferree et al., 1989a, 1992). The percentage of leaf area that was spur or shoot leaves was not influenced by training system. Specific leaf area (SLA) of spur leaves was not affected by training system, but the trellis system had a higher shoot SLA than the central leader. In a West Virginia study comparing the effects of five orchard systems, there were no differences in SLA of shoot leaves, but spur SLA of 'Golden Delicious' on the trellis was higher than on the central leader for 2 consecutive years (Ferree et al., 1989a).

The significant interaction between cultivar and system for spur density was due to the much higher density of spurs in the trellis than in the central leader system with 'Smoothee', while the other cultivars had similar spur densities in both systems. 'Lawspur' had a similar LAI in both systems, but the LAI of 'Smoothee' and 'Redchief' was lower in the central leader than in the trellis system. Spur density and LAI were much lower in the central leader for the standard-spaced trees than in the trellis system, with little difference between systems for the other treatments. 'Lawspur' had a lower density of spurs, LAI, spur leaf area, and percentage of leaf area that was spurs than the other two cultivars. Rom and Ferree (1984) found a close association of spur leaf area and long-term yield of nine apple cultivars. However, 'Rome Beauty' was not included in their study. The high yields of 'Lawspur' in this study would seem to contradict the close association of yield and spur leaf area. However, 'Lawspur' is a terminal-bearing cultivar that normally produces most of its fruit from terminal flower clusters with long bourse shoots and large cluster base. Voltz (1992) has shown the importance of the bourse shoot in fruit growth and calcium uptake of 'Granny Smith', another terminal-bearing cultivar. The importance of shoot growth for late-season fruit growth has also been demonstrated (Myers and Ferree, 1983; Rom and Ferree, 1986). Thus, the combination of the characteristics of terminal bearing, high canopy light transmission, large bourse leaf area, and normally later time of bloom make 'Lawspur' a large-fruited, high-yielding cultivar.

Planting the trees at half the in-row space and either hedging or root pruning increased the density of spurs and shoots and their respective leaf area per unit of canopy volume. LAI of 'Lawspur' and 'Redchief were higher in the closely planted and hedged or root-pruned trees, while the LAI of 'Smoothee' was not influenced by treatment. LAI was only slightly correlated with cumulative yield $(r=0.24)$. Both spur and shoot leaf area per canopy volume of 'Redchief were increased in hedged and root-pruned trees, with little effect of treatment on the other cultivars. Treatment did not influence the relative distribution of leaf type or their SLA.

When canopy height was divided into thirds, the middle third had a greater density of shoots, spurs, and a higher LAI and leaf area per canopy volume than the top or bottom thirds. The bottom level had more spur leaf area than the top, while just the opposite pattern existed for shoot leaf area. Shoot SLA declined from the top of the canopy to the bottom, while canopy level had no effect on spur SLA. When these trees were divided into thirds across the 
Table 3. Influence of mechanical root pruning or summer hedging of four apple cultivars in two orchard systems on canopy distribution.

\begin{tabular}{|c|c|c|c|c|c|c|c|c|c|}
\hline \multirow[b]{2}{*}{ Variable } & \multicolumn{3}{|c|}{ Density $/ \mathrm{m}^{3}$} & \multirow{2}{*}{$\begin{array}{l}\mathrm{LAI}^{\mathrm{y}} \\
\text { section }\end{array}$} & \multicolumn{2}{|c|}{$\begin{array}{l}\text { Leaf area/vol } \\
\qquad \mathrm{m}^{2} \cdot \mathrm{m}^{-3}\end{array}$} & \multirow{2}{*}{$\begin{array}{c}\text { Spur } \\
\text { area } \\
\text { (\% total) }\end{array}$} & \multicolumn{2}{|c|}{$\begin{array}{c}\mathrm{SLA}^{\mathrm{z}} \\
\left(\mathrm{mg} \cdot \mathrm{cm}^{-2}\right)\end{array}$} \\
\hline & Spurs & Shoots & Fruit & & Spur & Shoot & & Spur & Shoot \\
\hline \multicolumn{10}{|l|}{ System } \\
\hline Trellis & $23.3 a^{x}$ & $55.0 \mathrm{a}$ & $53.1 \mathrm{a}$ & $1.02 \mathrm{a}$ & $0.20 \mathrm{a}$ & $0.16 \mathrm{a}$ & $49.5 \mathrm{a}$ & $10.9 \mathrm{a}$ & $12.4 \mathrm{a}$ \\
\hline Central leader & $18.1 \mathrm{~b}$ & $45.5 \mathrm{~b}$ & $48.8 \mathrm{a}$ & $0.79 \mathrm{~b}$ & $0.13 \mathrm{~b}$ & $0.11 \mathrm{~b}$ & $50.6 \mathrm{a}$ & $10.9 \mathrm{a}$ & $11.1 \mathrm{~b}$ \\
\hline \multicolumn{10}{|l|}{ Cultivar } \\
\hline Smoothee & $24.9 \mathrm{a}$ & $62.5 \mathrm{a}$ & $39.5 \mathrm{~b}$ & $0.98 \mathrm{a}$ & $0.18 \mathrm{a}$ & $0.12 \mathrm{a}$ & $53.3 \mathrm{a}$ & $9.9 \mathrm{~b}$ & $11.1 \mathrm{~h}$ \\
\hline Lawspur & $12.2 \mathrm{~b}$ & $55.7 \mathrm{a}$ & $39.5 \mathrm{~b}$ & $0.67 b$ & $0.09 \mathrm{~b}$ & $0.17 \mathrm{a}$ & $37.9 \mathrm{~b}$ & $10.6 \mathrm{~b}$ & $12.2 \mathrm{a}$ \\
\hline Redchief & $24.3 \mathrm{a}$ & $32.5 \mathrm{~b}$ & $73.9 \mathrm{a}$ & $1.05 \mathrm{a}$ & $0.22 \mathrm{a}$ & $0.17 \mathrm{a}$ & $60.6 \mathrm{a}$ & $12.2 \mathrm{a}$ & $12.7 \mathrm{a}$ \\
\hline \multicolumn{10}{|l|}{ Treatment } \\
\hline Standard & $15.5 \mathrm{~b}$ & $35.7 \mathrm{~b}$ & $41.9 \mathrm{~b}$ & $0.70 \mathrm{~b}$ & $0.12 \mathrm{~b}$ & $0.11 \mathrm{~b}$ & $48.2 \mathrm{a}$ & $10.8 \mathrm{a}$ & $12.1 \mathrm{a}$ \\
\hline Hedged & $22.8 \mathrm{a}$ & $58.5 \mathrm{a}$ & $53.7 \mathrm{ab}$ & $0.97 \mathrm{a}$ & $0.17 \mathrm{a}$ & $0.13 \mathrm{a}$ & $51.0 \mathrm{a}$ & $10.8 \mathrm{a}$ & $11.9 \mathrm{a}$ \\
\hline Root pruned & $23.8 \mathrm{a}$ & $56.4 \mathrm{a}$ & $57.3 \mathrm{a}$ & $1.02 \mathrm{a}$ & $0.20 \mathrm{a}$ & $0.14 \mathrm{a}$ & $51.3 \mathrm{a}$ & $11.1 \mathrm{a}$ & $11.8 \mathrm{a}$ \\
\hline \multicolumn{10}{|l|}{ Canopy level } \\
\hline Top & $8.6 c$ & $35.3 \mathrm{~b}$ & $14.2 \mathrm{c}$ & $0.72 \mathrm{~b}$ & $0.09 \mathrm{c}$ & $0.14 \mathrm{~b}$ & $35.0 \mathrm{c}$ & $12.0 \mathrm{a}$ & $13.6 \mathrm{a}$ \\
\hline Middle & $33.3 \mathrm{a}$ & $81.0 \mathrm{a}$ & $87.8 \mathrm{a}$ & $1.16 \mathrm{a}$ & $0.21 \mathrm{a}$ & $0.17 \mathrm{a}$ & $51.2 \mathrm{~b}$ & $10.3 \mathrm{a}$ & $12.0 \mathrm{~b}$ \\
\hline Bottom & $20.1 \mathrm{~b}$ & $34.4 \mathrm{~b}$ & $45.9 \mathrm{~b}$ & $0.70 \mathrm{~b}$ & $0.15 \mathrm{~b}$ & $0.08 \mathrm{c}$ & $59.7 \mathrm{a}$ & $10.8 \mathrm{a}$ & $10.7 \mathrm{c}$ \\
\hline \multicolumn{10}{|l|}{ Canopy direction } \\
\hline East & $14.5 \mathrm{~b}$ & $40.1 \mathrm{~b}$ & $35.8 \mathrm{~b}$ & $0.76 \mathrm{~b}$ & $0.12 \mathrm{~b}$ & $0.12 \mathrm{~b}$ & $47.1 \mathrm{~b}$ & $11.0 \mathrm{a}$ & $12.2 \mathrm{a}$ \\
\hline Central & $35.0 \mathrm{a}$ & $75.1 \mathrm{a}$ & $86.2 \mathrm{a}$ & $1.07 \mathrm{a}$ & $0.22 \mathrm{a}$ & $0.15 \mathrm{a}$ & $54.4 \mathrm{a}$ & $10.3 \mathrm{a}$ & $12.1 \mathrm{a}$ \\
\hline West & $12.6 \mathrm{~b}$ & $35.5 \mathrm{~b}$ & $30.8 \mathrm{~b}$ & $0.77 \mathrm{~b}$ & $0.13 \mathrm{~b}$ & $0.11 \mathrm{~b}$ & $47.0 \mathrm{~b}$ & $11.7 \mathrm{a}$ & $11.6 \mathrm{a}$ \\
\hline \multicolumn{10}{|l|}{ F significance } \\
\hline Cultivar (C) & $* *$ & $* *$ & $* *$ & $* *$ & $* *$ & NS & $* *$ & $* *$ & $* *$ \\
\hline System (S) & $* *$ & * & NS & $* *$ & $* *$ & $* *$ & NS & NS & $* *$ \\
\hline $\mathrm{C} \times \mathrm{S}$ & $* *$ & NS & NS & $* *$ & NS & $* *$ & NS & NS & $*$ \\
\hline Treatment (T) & $* *$ & $* *$ & $*$ & $* *$ & $* *$ & $*$ & NS & NS & NS \\
\hline $\mathrm{C} \times \mathrm{T}$ & $* *$ & NS & NS & $* *$ & $* *$ & $* *$ & NS & NS & NS \\
\hline $\mathrm{S} \times \mathrm{T}$ & $* *$ & NS & NS & $* *$ & NS & $*$ & $*$ & NS & NS \\
\hline Level (L) & $* *$ & $* *$ & $* *$ & $* *$ & $* *$ & $* *$ & $* *$ & NS & $* *$ \\
\hline $\mathrm{C} \times \mathrm{L}$ & $*$ & NS & $* *$ & NS & NS & NS & NS & NS & NS \\
\hline $\mathrm{S} \times \mathrm{L}$ & NS & NS & NS & NS & NS & NS & NS & NS & NS \\
\hline $\mathrm{T} \times \mathbf{I}$ & $* *$ & NS & NS & NS & NS & NS & NS & NS & $*$ \\
\hline Direction (D) & $* *$ & $* *$ & $* *$ & $* *$ & $* *$ & $*$ & $* *$ & NS & $* *$ \\
\hline$C \times D$ & $* *$ & NS & $*$ & $* *$ & * & * & NS & NS & NS \\
\hline $\mathrm{S} \times \mathrm{D}$ & $* *$ & $* *$ & $* *$ & $* *$ & $* *$ & NS & $* *$ & NS & $*$ \\
\hline $\mathrm{T} \times \mathrm{D}$ & NS & NS & NS & NS & NS & NS & NS & NS & NS \\
\hline $\mathrm{L} \times \mathrm{D}$ & $* *$ & $* *$ & $* *$ & $*$ & $* *$ & $* *$ & $* *$ & NS & NS \\
\hline
\end{tabular}

${ }^{\overline{2}} \mathrm{SLA}=$ specific leaf area (dry weight leaf area).

${ }^{y} \mathrm{LAI}=$ leaf area index per canopy section.

'Mean separation within main effect column by Duncan's multiple range test, $P \leq 0.05$. Data are means of the following number of observation: system, 162; cultivar, 108; treatment, 108; canopy level, 108; canopy direction, 108 .

${ }_{\text {Ns, }}^{*},{ }^{* *}$ Nonsignificant or significant at $P \leq 0.05$ or 0.01 , respectively.

row, the central canopy section had the greatest density of spurs, shoots, and fruit and the highest LAI and leaf area per volume of both leaf types. The various foliage characteristics had the following low correlations to cumulative yield per hectare: LAI, $r=0.24$; total shoot leaf area, $r=0.38$; percentage spur leaves, $r=(-0.24)$; percentage shoot leaves, $r=0.24$. Spur density and LAI were much higher in the central section of the trellis than the central leader, with little differences between systems in the east and west sides of the canopy. The interaction between direction and level generally was due to the increase in spur leaf area per canopy volume in the middle and bottom levels of the canopy sections. Shoot leaf area in the top central section was much higher than the top in the east and west sides of the canopy.

Light transmission measured $15 \mathrm{~cm}$ from the trunk at a height of $1 \mathrm{~m}$ did not differ whether taken on an overcast or cloud-free day. 'Smoothee' and 'Redchief' trees had higher light transmis- sion levels in the central leader than in the trellis, while the reverse occurred in 'Lawspur' trees (Fig. 2). There was no difference in percentage photosynthetic photon flux transmission (PPFT) between systems in hedged and root-pruned trees. However, standard-spaced trees in the central leader system had higher PPFT values than those in the trellis system.

A ranking of the long-term investment potential of the 24 treatments was determined using NPV analysis. The 10-year stream of net revenues (benefits minus costs) were discounted at an annual interest rate of $10 \%$ to reflect the opportunity cost associated with holding a long-term investment. Total benefits were measured by the discounted value of the salable fruit produced under each treatment, less annual operating and overhead expenses. Resulting NPV values ranged from $-\$ 16,575$ to $-\$ 34,245$ (Table 4). While all NPVs were negative, a result indicating unprofitable investment alternatives, the ranking of treatments and 

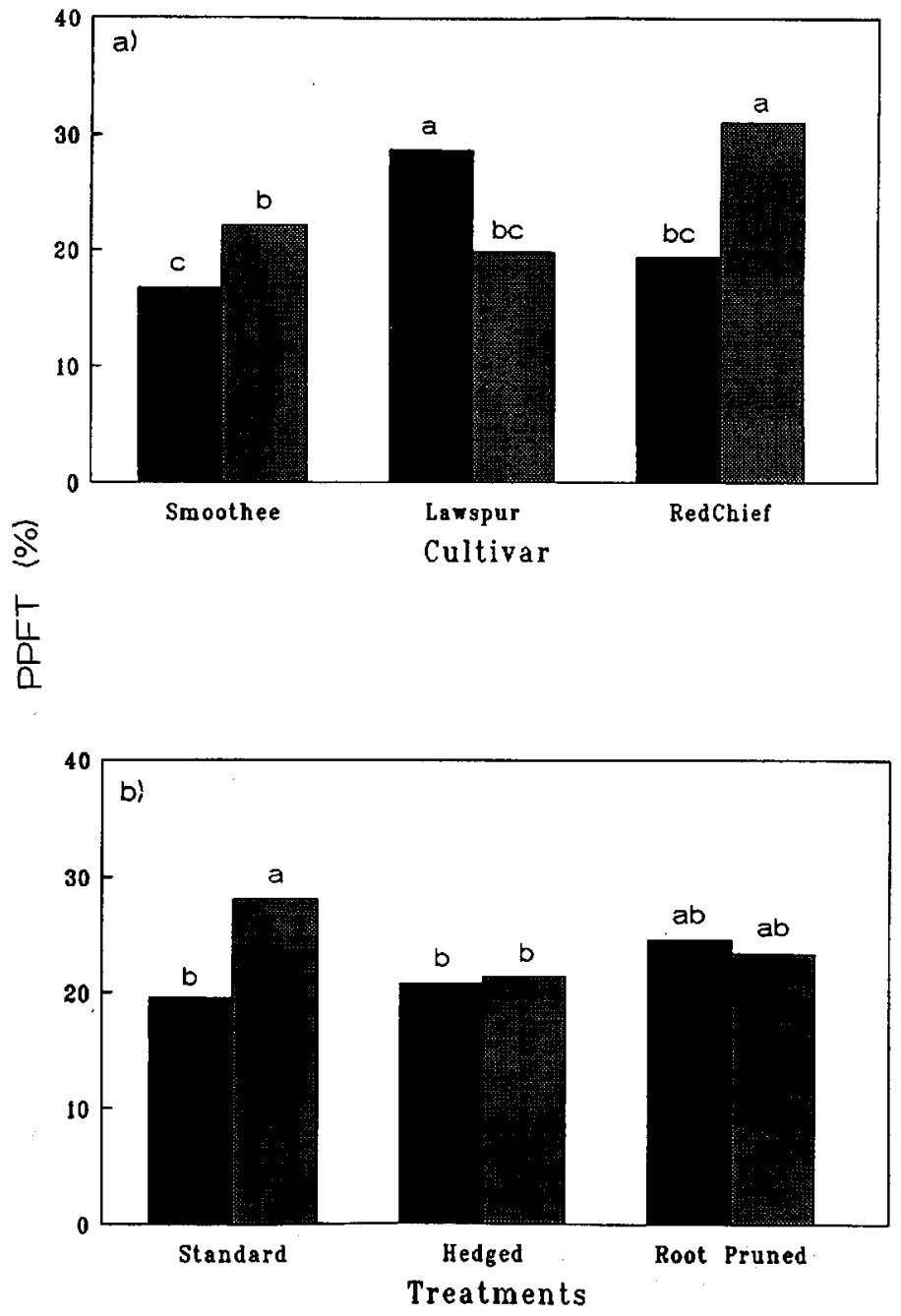

Fig. 2. Interaction of the trellis (left bars) and central leader (right bars) orchard management system and (a) cultivar or (b) mechanical pruning treatment on photosynthetic photon flux transmission in the tree canopy. Data are means of nine and six observations for cultivar and treatment, respectively.

cultivars by NPV is worth noting.

In a previous long-term study (Ferree et al., 1989b), 'Golden Delicious' trained as central leaders had $63 \%$ and as a trellis $25 \%$ higher cumulative yields over 10 years than trees in this study. Trees in both of these systems had a positive internal rate of return by year 7 . The lower yield of trees in the present study was likely due to winter injury that resulted from a freeze on 24 Dec. 1983, when the temperature dropped from -15.6 to $-25 \mathrm{C}$, with high winds and no snow cover. A rating of the trees (Schupp and Ferree, 1986) indicated some injury on 'Smoothee' and 'Empire' with more severe injury on 'Lawspur' and 'Redchief'. There was very little mortality over the 10 years of this study, but the effects of winter injury on the trees likely affected yields for several years. Of the widely used rootstocks, M.7 is the most sensitive to winter injury (Quamme, 1990), and tree loss and injury in Ohio (Chandler and Ferree, 1990) verified its sensitivity. The sensitivity of M.7 may explain the much lower yields of trees in the central leader system in this trial compared to the earlier study.

Of the top 12 treatments ranked by NPV, nine were the central leader system, which entails lower establishment and annual maintenance costs. In a previous study, the central leader system also had the highest internal rate of return over 11 years (Ferree et al., 1989b). Of the top three trellis system treatments, none was hedged or root-pruned. Thus, the increased investment due to doubling the number of trees and the additional machinery and labor expenses were not justified. The highest yielding cultivar, 'Lawspur', ranked in four of the top six treatment groups. A high yielding cultivar was critical to the profitability of all systems. The trellis system proved more profitable only in conjunction with the standard-spacing treatment (trellis). Costs associated with doubling the tree density and controlling growth with hedging or root pruning negate the yield advantages of the trellis system. Finally, the lower-cost central leader system offers greater investment potential over the long run, but the NPV analysis was inconclusive as to the benefits of root pruning or hedging under this system.

In summary, hedging and root pruning can be used to contain apple trees planted at half the recommended in-row spacing. However, the reduced tree efficiency in the trellis and central leader systems resulted in minimal cumulative yield increases and no apparent economic advantage. Orchard intensification through the trellis system resulted in much higher cumulative yields for all cultivars except 'Lawspur', when planted at the standard spacing. We conclude that it is better to plant systems at a spacing that avoids excessive crowding so that mechanical means of controlling size, such as hedging or root pruning, are not necessary annually.

\section{Literature Cited}

Barritt, B.H. 1989. Deciding on a high density orchard system, p. 89-96. In: A.B. Peterson (ed.). Intensive orcharding. Good Fruit Grower, Yakima, Wash.

Chandler, C.K. and D.C. Ferree. 1990. The winter of 1983-84. A test winter for Ohio's fruit crops. Fruit crops 1990: A summary of research. OARDC Res. Circ. 297:23-24.

Elfving, D.C., E.C. Lougheed, and R.A. Cline. 1991. Daminozide, root pruning, trunk scoring, and trunk ringing effects on fruit ripening and storage behavior of 'McIntosh' apple. J. Amer. Soc. Hort. Sci. 116: 195200.

Ferree, D.C. 1976. Influence of slotting saw mechanical pruning and alar on apple fruit size and quality. Ohio Agr. Res. Circ. 220:3-7.

Ferree, D.C. 1979. Effects of selected dormant pruning techniques in a hedgerow apple orchard on M.26. J. Amer. Soc. Hort. Sci. 104:736-739.

Ferree, D.C. 1992. Time of root pruning influences growth, fruit size, biennial bearing, and yield of 'Jonathan' apple. J. Amer. Soc. Hort. Sci. 117:198-202.

Ferree, D.C., J.C. Schupp, S.H. Blizzard, T.A. Baugher, and I.J. Warrington. 1989a. Influence of five orchard management systems on canopy composition, light penetration and net photosynthesis of 'Golden Delicious' apple. Acta Hort. 243:131-140.

Ferree, D.C., K. Clayton-Greene, and B. Bishop. 1993. Influence of orchard management system on canopy composition, light distribution, and net photosynthesis on apple trees. J. Hort. Sci. 68:377-392.

Ferree, D.C., M.A. Ellis, and F.R. Hall. 1983. Tree loss due to fireblight infection of rootstocks and interstems in Ohio apple orchards. Compact Fruit Tree 16:116-120.

Ferree, D.C., R.C. Funt, and B.L. Bishop. 1989b. Yield and production efficiency of four apple cultivars in selected orchard management systems. J. Amer. Soc. Hort. Sci. 114:863-868.

Geisler, D. and D.C. Ferree. 1984. Response of plants to root pruning. Hort Rev. 6: 155-188.

Hoblyn, T.N., N.H. Grubb, A.C. Ranter, and B.L. Wates. 1936. Studies in biennial bearing. J. Pomol. Hort Sci. 14:39-76.

Jackson, J.E. and J.W. Palmer (eds.). 1989. Fourth International Symposium on research and development in orchard and plantation systems. Acta Hort. 243:1-408.

Lespinasse, J.M. 1980. Fruiting habits of apple and how they influence tree forms. (translation by R.L. Stebbins). Fruit Belge. 391-393.

Myers, S.C. and D.C. Ferree. 1983. Influence of time of summer pruning and limb orientation on yield, fruit size, and quality of vigorous 'Deli- 


\begin{tabular}{|c|c|c|c|c|c|}
\hline Rank & Cultivar & Treatment & System & $\begin{array}{c}\text { Net } \\
\text { present } \\
\text { value }(\$)\end{array}$ & $\begin{array}{c}\text { Difference } \\
\text { from Rank } 1 \\
(\$)\end{array}$ \\
\hline 1 & Redchief & Hedged & Central leader & $-16,574$ & 0 \\
\hline 2 & Lawspur & Standard & Trellis & $-16,784$ & -210 \\
\hline 3 & Lawspur & Standard & Central leader & $-18,082$ & $-1,508$ \\
\hline 4 & Lawspur & Root-pruned & Central leader & $-18,132$ & $-1,558$ \\
\hline 5 & Lawspur & Hedged & Central leader & $-19,874$ & $-3,300$ \\
\hline 6 & Smoothee & Standard & Trellis & $-20,263$ & $-3,689$ \\
\hline 7 & Empire & Standard & Trellis & $-21,353$ & $-4,779$ \\
\hline 8 & Snioothee & Standard & Central leader & $-21,371$ & $-4,797$ \\
\hline 9 & Empire & Standard & Central leader & $-21,577$ & $-5,003$ \\
\hline 10 & Empire & Root-pruned & Central leader & $-21,988$ & $-5,414$ \\
\hline 11 & Redchief & Standard & Central leader & $-22,878$ & $-6,305$ \\
\hline 12 & Smoothee & Root-pruned & Central leader & $-22,929$ & $-6,355$ \\
\hline 13 & Redchief & Root-pruned & Central leader & $-23,404$ & $-6,831$ \\
\hline 14 & Redchief & Standard & Trellis & $-23,586$ & $-7,012$ \\
\hline 15 & Empire & Hedged & Central leader & $-24,574$ & $-8,000$ \\
\hline 16 & Smoothee & Root-pruned & Trellis & $-25,097$ & $-8,523$ \\
\hline 17 & Smoothee & Hedged & Central leader & $-25,440$ & $-8,866$ \\
\hline 18 & Empire & Hedged & Trellis & $-26,156$ & $-9,582$ \\
\hline 19 & Empire & Root-pruned & Trellis & $-28,072$ & $-11,499$ \\
\hline 20 & Lawspur & Hedged & Trellis & $-28,503$ & $-11,929$ \\
\hline 21 & Smoothee & Hedged & Trellis & $-30,286$ & $-13,712$ \\
\hline 22 & Lawspur & Root-pruned & Trellis & $-32,954$ & $-16,380$ \\
\hline 23 & Redchief & Root-pruned & Trellis & $-33,420$ & $-16,846$ \\
\hline 24 & Redchief & Hedged & Trcllis & $-34,245$ & $-17,671$ \\
\hline
\end{tabular}

cious' apple trees. J. Amer. Soc. Hort. Sci. 108:630-633.

Ohio Cooperative Extension Service. 1991. Ohio enterprise budget specialty crops. Ohio Coop. Ext. Serv. Bul. nn-389.

Quamme, H.A. 1990. Cold hardiness of apple rootstocks. Compact Fruit Tree 23: 11-16.

Robinson, T.L. and A.N. Lakso. 1991. Bases of yield and production efficiency in apple orchard systems. J. Amer. Soc. Hort. Sci. 116:188194.

Robinson, T.L., A.N. Lakso, and S.G. Carpenter. 1991. Canopy development, yield and fruit quality of 'Empire' and 'Delicious' apple trees grown in four orchard production systems for ten years. J. Amer. Soc. Hort. Sci. 116:179-187.

Rom, C.R. and D.C. Ferree. 1984. Spur leaf characteristics of nine apple cultivars. Fruit Var. J. 38:2-5.

Rom, C.R. and D.C. Ferree. 1986. The influence of fruiting and shading of spurs and shoots on spur performance. J. Amer. Soc. Hort. Sci. 111:352-356.

Scibsz, K. 1990. Effect of different retarding factors upon growth and yield of apple trees. XXIII Intl. Hort. Congr. Oral Abstr. 1682:307.

Schumacher, R. 1975. Einfluss des wurzelschnittes, auf die fruchtbarkeit von apfelbläumen, Schweiz. Zeitschr, für Obst-Und Weinbau 11(5):115116.

Schupp, J.R. and D.C. Ferree. 1986. Little relationship between root pruning and winter injury. Fruit crops 1986: A summary of research. OARDC Res. Circ. 290: 17-18.

Schupp, J.R. and D.C. Ferree. 1987. Effect of root pruning at different growth stages on growth and fruiting of apple trees. HortScience 22:387-390.

Schupp, J.R. and D.C. Ferree. 1988. Effects of root pruning at four levels of severity on growth and yield of 'Melrose'/M.26. J. Amer. Soc. Hort. Sci. 113:194-198.

Schupp, J.R., D.C. Ferree, and I.J. Warrington. 1992. Interactions of root pruning and deblossoming on growth, development and yield of 'Golden Delicious' apple. J. Hort. Sci. 67(4):465-480.

Voltz, R.K. 1992. Fruit quality and productivity on apple replacement branches. Ph.D. thesis, Massey Univ. 